\title{
Sustainable Development and Livelihoods of Rohingya Refugees in Bangladesh: The Effects of COVID-19
}

\author{
A N M Zakir Hossain ${ }^{1,2}$ \\ ${ }^{1}$ Doctoral School of Public Administration Sciences, Faculty of Public Governance and International Studies, National \\ University of Public Service, Budapest 1083, Hungary \\ ${ }^{2}$ Department of Agricultural Economics, Bangladesh Agricultural University, Mymensingh 2202, Bangladesh
}

Corresponding Author Email: anmzakirhossain@bau.edu.bd

https://doi.org/10.18280/ijsdp.160615

Received: 5 August 2021

Accepted: 30 September 2021

\section{Keywords:}

Rohingya, COVID-19, refugee, livelihoods, sustainable development,

Bangladesh

\begin{abstract}
Bangladesh is one of the top refugee-hosting countries of the world and adversely affected by the COVID-19. This paper aims to identify how the COVID-19 pandemic affects the Rohingya refugee and expose the vulnerability that challenges SDGs. The study follows a system approach grounded on a sustainable development model and uses secondary sources of data. The study found that fragmented and random policies in refugee crisis management during the COVID-19 reveals the policy lacks structural fragility due to inadequate policy and programs. Besides, the limited number of health care, food, education, washing facilities, housing, and the utilization of inferior materials in camps put pressure on the refugee health, education, and well-being during COVID-19. It also reduces the monetary funds, which affects humanitarian support, and limits the aid to SDGs in refugee camps due to restrictive policies. Moreover, refugees' inability to include an inclusive social security system is far from existing social inequality. This paper calls for robust policies and programs with adequate funding for structural logistics and effective service delivery in refugee management for their future wellbeing and promoting SDGs in refugee camps.
\end{abstract}

\section{INTRODUCTION}

The number of refugees has lifted radically and challenged sustainable development in the contemporary world [1]. The figure of displaced people worldwide is about 80 million, including refugees. Bangladesh is one of the most densely populated and top refugee-hosting countries in the world. The COVID-19 pandemic adversely affects Bangladesh [2] like other countries, irrespective of location and economic situation. Refugees are the most vulnerable community to a crisis like COVID-19 and living with an ocean of miseries [3]. Rohingya refugees pass perilous lives with many violations and vulnerabilities in human rights [4] and opportunities both in Bangladesh and Myanmar since decolonization and persecution [5]. Now they live in the world's most densely populated refugee camps in Bangladesh. Besides, Bangladesh is a non-signatory country to the convention of refugee 1951 and protocol 1967, which stepped them behind to offer the basic rights to the Rohingya refugee population. A refugee is defined as a person "who is unable or unwilling to return country of origin owing to we-founded fear of being persecuted for reasons of race, religion, nationality, membership of a particular social group, or political opinion" [6].

The global refugee situation is worsening by the evil effects of the COVID-19 pandemic [7]. The refugee and displaced people are suffering worldwide, including Rohingya. The reasons for displacement can vary for refugees and displaced people; however, it results in more or less uniform vulnerabilities for them regardless of their region of culture and political situation [8]. These people need emergency support for their safety and security. It is also essential for sustainable growth of their children and youth, who can contribute to the community in future. In the $21^{\text {st }}$ century, refugee management in any country requires a set of logistics that primarily helps to settle down then guides them for their basic needs. Bangladesh could not arrange such type of organizational arrangement for them from the beginning of the crisis. At the same time, Bangladesh is not a signatory to any international convention on refugee management. In contrast, Myanmar was the place of anxiety- a prolonged civil war, the struggle for democracy made the place hostile for many years for all inhabitants [9]. The British colonial power founded the political landscape of Myanmar with a fragile architectural base that used different ethnic groups against them to cemented their rule. It has a significant impact on the government of independent Myanmar, which yields several challenges for both the government and the people. However, the government dominated Rohingya people and continuously excluded them from the exclusiveness of mainland Myanmar politics for more than fifty years $[10,11]$. Rohingya are the most notable displaced people in the Asia Pacific region who left their homeland due to military atrocities in Myanmar. As a result, the Rohingya community felt trouble since their independence from the colonial power and dropped into a crisis of identity [12]. They are also deprived of fundamental rights within Myanmar. Bangladesh hosts a million of displaced Rohingya that started in 1978 and augmented in 2017. Finally, it became the highest total displaced people in Southeast Asia [13]. 
The refugee-hosting third-world countries are struggling worldwide, after the outbreak of COVID-19, with the refugee for migration, movement, and humanitarian support. They are passing turbulent times and fronting various challenges. The hosting country governments became stagnant, while a few countries failed to ensure their rights and protection [14]. The epidemic outbreak affects the refugees worldwide. It also creates anxiety in refugee camps as social distancing for epidemic control measures is not practical due to their current situation [15]. However, it is crucial to ensure and maintain minimum standard space to avoid the COVID-19 infection, which is not practical in their camps as it is highly congested. The COVID-19 virus does not affect all evenly, though the poor people are susceptive to this pandemic due to several vulnerabilities. The coronavirus is also dangerous for refugees and displaced people because of their communicative and noncommunicative diseases and chronic health conditions. It is crucial to revisit the effects of the current COVID-19 pandemic on Rohingya refugees; however other studies focus on refugees and their sustainability in different countries [16]. The previous studies on Rohingya refugees are fragmented [17, 18], which are not inclusively concentrate on the Sustainable Development Goals (SDGs) and other demographic issues. As a result, this study is a significant attempt to explore the recent COVID-19 effect on their daily lives at their camps, where they live without maintaining standard health safety and social distances.

This study attempts to explore the diverse effects of the contemporary COVID-19 pandemic on the Rohingya refugee lives and well-being to achieve SDGs in the refugee camps. The scholarship endeavors to answer questions related towhat conditions put pressure on existing crises due to the COVID-19? To what extent it impacted on refugee lives and safety in their camps? How do the hosting country with other humanitarian agencies manage refugee rights and security crises to ensure sustainable development? Thus the scholarship offers an insight to draw attention to the role of local and international humanitarian agencies and the host government to ensure the safety, security, and rights of Rohingya for their future well-being in general and SDGs in particular in refugee camps.

\section{MATERIALS AND METHODS}

The study focuses on the Rohingya refugees who fled from Myanmar and lived with numerous vulnerabilities in the refugee camps at Cox's Bazar, Bangladesh. The study followed a system approach [19] and used secondary sources of data. The scholarship is theoretically grounded on the sustainable livelihoods and sustainable development model to answer the research questions and attain the research objectives. The author gathered data from prevailing literature and evidence on COVID-19 effects on Rohingya refugee people in Bangladesh from different sources. The author has chosen this approach due to the current covid situation, continuous lockdown, and repeated policy changes in domestic COVID-19 infection control measures. Besides, it allows getting more extensive data from various sources to represent the holistic scenario of the general services and future challenges of refugee people. The Rohingya refugee people constitute about one million, where more than half are children, and about fifty percent are women. The COVID-19 pandemic initially created a global crisis for refugee funding and a shortage of frontline service providers worldwide due to the global economic downturn. Simultaneously, the COVID19 pandemic adversely affected different demographic areas, including Rohingya, from a different context in Bangladesh. Rohingya people are susceptive to infection due to their current situation and way of living in congested camps, which challenge SDGs.

The author gleaned data from various reliable sources relevant to the research. To achieve the research goals, the author garnered data sources from PubMed, ProQuest, Science Direct, Web of Science, Google Scholar, and grey literature from the refworld, UNICEF, UNFPA, WHO, etc. The key words included COVID-19 and common terms connected the subject- 'Rohingya refugee,' 'COVID-19 and Rohingya', 'Rohingya refugee and COVID-19', 'COVID-19 and refugee health', 'impact of COVID-19 on refugee' 'COVID-19 and security of refugee', 'COVID-19 and financing refugee' and 'health and education of refugees,' 'refugee and humanitarian agencies.' The author included both the research article and reports of different organizations published in English and excluded the redundant studies where the full text was unavailable- then exported all the identified records into Mendeley ${ }^{\mathrm{TM}}$, where the duplicate articles were erased. Then to fulfill the eligibility criteria of inclusion, the titles and abstracts were screened for full-text screening. All the related items were evaluated for suitability for the study based on their titles and potential citations. The relevant data were mined from assessing the full text of the associated articles and reports based on the position, presence, and keywords of interest. At the same time, all the articles and reports were included in the Rohingya refugee context.

The item of textual analysis of the scholarship was Rohingya refugee and COVID-19. Further, the author comprised health, education, mortality, income opportunity, and NGOs working on health, education, environment, and agents of donor agencies and government organizations. In addition, the author intentionally selected these to garner relevant and authenticated inquiries on the effects of COVID19 on Rohingya refugees and the potential innovations in refugee management for supporting SDGs. Moreover, the author included the teachers, health service providers, physicians and caregivers, and the relevant humanitarian agencies providing humanitarian support in the Rohingya refugee camps. The author intended to explore the various impact of the COVID-19 pandemic on refugee lives.

The author finally strived to collect information about the effects of COVID-19 on refugee people from different secondary sources to identify the extent and magnitudes of the current pandemic. Non-refugee was also a fundamental unit of analysis for the study as the COVID-19 pandemic jeopardized the existing governance for both the refugee and host society. In addition, the study intends to discover the plans to improve the refugee management system in camps for the Rohingya in the coming days. Furthermore, the author tried to explore the innovative measures taken for Rohingya refugees in this pandemic. Therefore, the author included all to get rich and widespread data and make the arguments nuanced and authentic. The author executed this to facilitate the validity of the data gleaned from different sources to reach conclusions on SDGs for Rohingya. 


\section{DEMOGRAPHY OF ROHINGYA REFUGEE IN BANGLADESH}

The Rohingya started to flee from Myanmar to Bangladesh in 1978 [20]. Since then, the practice of a political culture of these communities was to repatriate again to Myanmar when they felt the situation was normal to get back home. But this practice has been discontinued since 1999. The government of Myanmar expelled millions of Rohingya over the years, seized their rights and opportunities, and imprisoned them inside the Rakhine [21]. The significant influx of Rohingya in Bangladesh happened in august 2017, and millions of Rohingya people left Rakhine when the ethnic cleansing was started by the Myanmar military (Figure 1). These people joined the Rohingya who were already in Bangladesh since 1999.

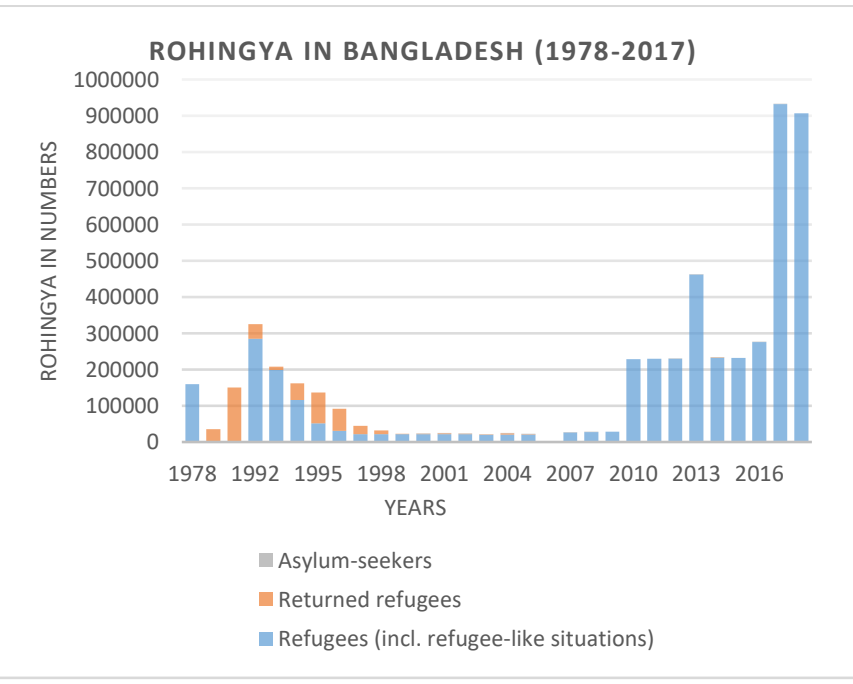

Figure 1. Rohingya refugee in Bangladesh [11]

The Rohingya refugees in Bangladesh comprised fifty-one percent of children and forty-nine percent of adults. The adults sub-grouped into two groups where only four percent are aged more than sixty years, and the remaining are within eighteen to fifty-nine years old (Table 1). The Rohingya refugee children are combined with three different sub-groups from 0 to 4,5 to 11 , and $12-17$ years, where the group share is 15,22 , and 14 percent, respectively (Figure 2). This dominant group of Rohingya populations needs extra care and attention during the COVID-19 crisis. They are more vulnerable to and under limited food, health, education, and other essential services in their camps in Bangladesh [22].

Table 1. Gender distribution of Rohingya refugee based on age [23]

\begin{tabular}{ccccc}
\hline \multirow{2}{*}{ Age Group } & Male & Female & Total & \\
\cline { 2 - 5 } & $\mathrm{n}(\%)$ & $\mathrm{n}(\%)$ & $\mathrm{n}(\%)$ & \\
\hline Infant-4 years & 8 & 7 & 15 & Total Children \\
5-11 years & 11 & 11 & 22 & $\mathbf{5 1}$ \\
12-17 years & 7 & 7 & 14 & \\
\hline $18-59$ & 20 & 25 & 45 & Total adult \\
60+ & 2 & 2 & 4 & $\mathbf{4 9}$ \\
\hline Total & $\mathbf{4 8}$ & $\mathbf{5 2}$ & $\mathbf{1 0 0}$ & \\
\hline
\end{tabular}

Source: UNHCR 2020a

It is recognized globally that women and children are most vulnerable to a crisis, and the COVID-19 pushed this vast community with an extra load of trauma and tension with other existing vulnerabilities [24]. The figure of the refugee population has clearly shown that seventy percent of the children are adolescents who need additional support as they are suffering trauma and stress.

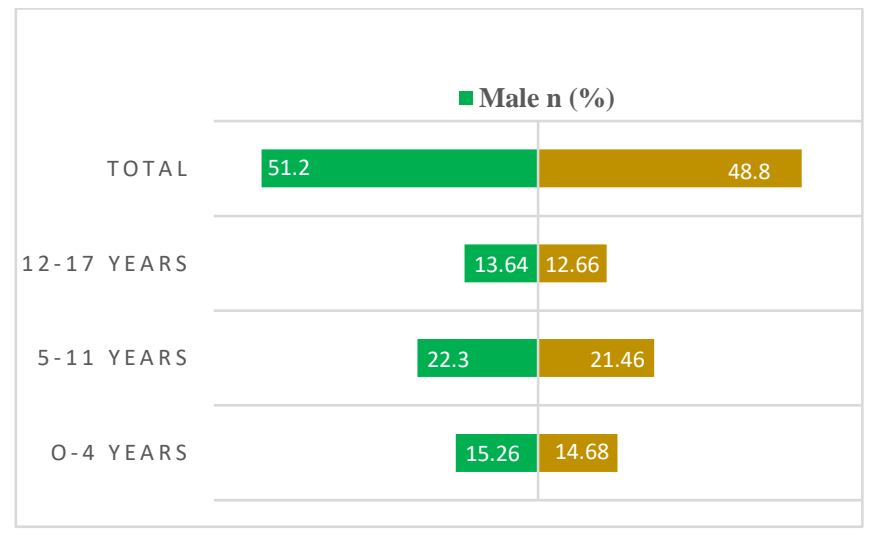

Figure 2. Demography of refugee children in Bangladesh [23]

The COVID-19 has griped them in a cycle of enduring miseries. These children are traumatized, mourned, living below poverty, and within a broken family, and deeply shocked [25]. On an emergency basis, the infant children need emergency support in immunization, vitamin capsules, and other essential services for their well-being in the refugee camps with other pregnant women.

\section{SUSTAINABLE DEVELOPMENT AND SUSTAINABLE LIVELIHOOD FRAMEWORK OF ROHINGYA REFUGEE}

Rohingya refugee people are vulnerable from various contexts and aspects- socio-cultural, economic, environmental, safety, security, and status. The socio-cultural context of refugees combined their social rank (Majhee, Imam, and religious person), age, education, and disabilities with and without chronic diseases in the refugee camps. Their gender plays a crucial role in determining their recognition in the existing society. Rohingya people do not get an equal economic opportunity. Their economic vulnerability extended by the size and type of the households, while limited access to information also hampers their economic life [26]. Besides, the age and gender differences of Rohingya affect their gender-based violence, harassment, nutritional status, also early marriage puts pressure on socio-cultural vulnerability.

In refugee camps, human trafficking and drug trafficking, organized crime with robbery, kidnapping, and violence deposit safety and security tension for them [27]. Environmental hazards are also common in refugee camps, as Bangladesh is a disaster-prone country, and camps locate in a vulnerable place in the southern part of Bangladesh [28-30]. Due to continuous pressure for shelter construction and location, floods, landslide, and the threat of wild animals in refugee camps made them environmentally vulnerable [31]. The absence of lifting mechanisms from safety and security crises and environmental vulnerability create room for the refugee people to involve with the agitated organized armed group. However, all these vulnerabilities affect their lives, but these refugees' status has significantly impacted their refugee- 
hood in Bangladesh. Many old Rohingya refugees received refugee status, but many are accepted and registered as a refugee after the major influx, while many are registered as displaced Myanmar nationals. These are producing service variability due to their status in Rohingya refugee camps in Bangladesh. This study calls for the connection of COVID-19 effects on the lives of Rohingya refugee people in light of sustainable livelihoods for achieving sustainable development goals during their refugee-hood.
The inclusive policies for food security, education, safety, and the diversifications of livelihoods through economic inclusion can offer a decent life for the refugee for their future to support their sustainable development in the coming days. The availability and adequate logistics for continuous support service for the Rohingya can embolden their potentials to develop their livelihoods for achieving sustainable development goals even in their distress journey (Figure 3).

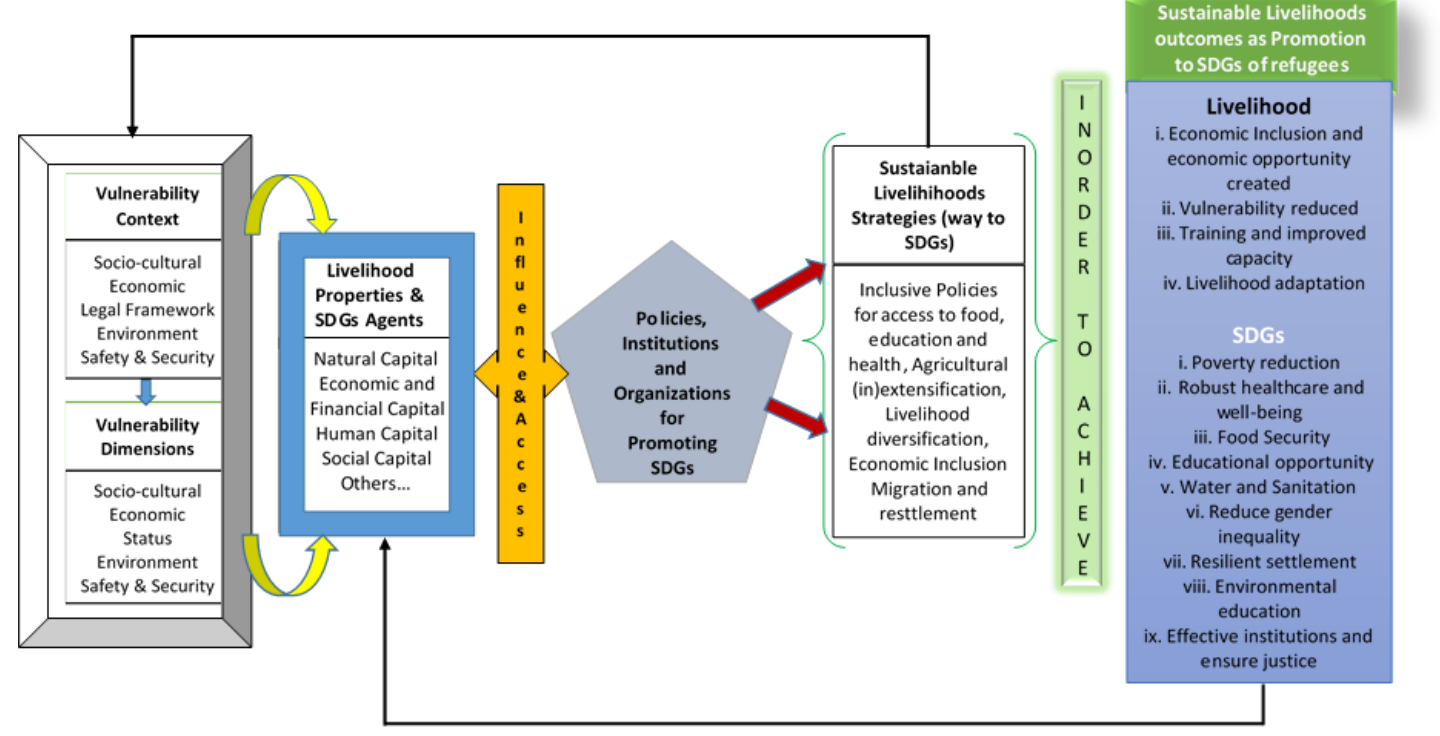

Figure 3. Sustainable livelihoods and SDGs: A framework for sustainable refugee livelihoods (Modified from DFID) [32]

\section{THE COVID-19 PANDEMIC EFFECTS ON SUSTAINABLE DEVELOPMENT AND SUSTAINABLE LIVELIHOODS OF ROHINGYA REFUGEE}

Notwithstanding the noteworthy improvement in Rohingya refugee camps, the outbreak of the COVID-19 pandemic manifests challenges and worsens the inclusive safety and security environment in the refugee camps. The limited availability of regular facilities and the presence of limited numbers of humanitarian agencies aggravated the pre-existing vulnerabilities of women, adolescents, children, elders, girls, and others with disabilities. This situation remains as many regular activities are not resumed yet due to the current COVID-19 crisis in Bangladesh. As a result, their limited numbers in the refugee camps in response to the humanitarian supports caused a vacuum in conflict, negotiations, and other legal services. The COVID-19 pandemic has multidimensional effects on refugee lives that need to address immediately. The study suggests adequate policy measures to encounter the evil effects on their lives.

\subsection{Effects on the healthcare system of Rohingya [SDG-3]}

The healthcare system is under stress all over the world after the coronavirus outbreak. The Government of Bangladesh (GoB) also faces several challenges to nationwide control of the death and infection rate. Government adopts different policies to support adequate logistics for increasing the number of tests to detect the disease [15]. In response to COVID 19, the World Health Organization (WHO), GoB, and other local and international NGOs deliver healthcare support to more than 1 million people in Rohingya refugee camps, which become a hotspot for fast transmission of the virus [33]. Their joint efforts succeeded in many ways to reduce the mortality rate and to respond to various emergency issues of men, women, and children. The GoB and WHO work together with other partners to develop action plans to implement in the camps. They also monitor their activities and connect local communities to engage them in the development programs. They also work with other stakeholders to respond against the COVID-19 to protect the people and their community.

The Rohingya refugee lives under extreme vulnerability. They suffer from extensive challenges concerning diseases outburst and interruption of basic facilities in their camps. So, continuous funding and support are essential to sustain the earlier achievements through combined efforts to ensure and develop future resilience. In response to COVID-19, health care facilitators received training on hygiene. Refugees were given improved services in modernized clinics, sub-health centers, permanent clinics, and immunizations. Moreover, hospitals organize regular health-related awareness programs to enhance the existing healthcare facilities in refugee camps [34].

Furthermore, many initiatives are highly welcomed by the refugees, such as responding to the social safety net program, adapted programs to prevent child marriage, increasing numbers and amount of disability allowances, food for poor people, rehabilitation for sick and elderly, and widows. Necessary steps have already been taken to expand the washing facility, improve the drainage system, alleviate the water-logging channels, installations of deep tube well for drinking water, and supply pure water at religious centers. The 
hygienic and sanitary equipment was also provided at the washing centers and increased the number of washing centers at the refugee camps. However, to maintain the current services, there is a considerable gap in funding between the requested $(\$ 181.1 \mathrm{M})$ and received $(\$ 72.1 \mathrm{M})$ amount of the grants for refugee healthcare. In addition, the COVID-19 epidemic warrants emergency support that diverted attention from regular healthcare services for women and children [35] (i.e., sexual and reproductive, immunization) and their mental health (Figure 4). The information gap, limited access to health services, and existing rumors in the camps extended the service gap during COVID-19. It also built a mistrust between the humanitarian agencies and healthcare facilities. The disabled and aged people typically have limited access to available information and services [36], who have experienced additional hurdles to avail continuous services because of current restrictive norms and social stigma. The study reports that the negative health-seeking attitude during COVID-19 lifted the numbers for a routine examination. While women and girls also fall into trouble seeking healthcare support due to less space for gender-segregated services in healthcare centers [14]. The male counterparts are reluctant to join and stay in mixed isolation treatment facilities for their female family members.

In contrast, females and girls do not feel safe in a mixed treatment facility because of GBV and abuse risk. As a result, the situation in the refugee camps becomes terrifying as the outbreak of COVID-19 limits other health-related practices [37] and minimizes the essential health services. It also intensifies pressure on achieving sustainable development goals for refugees.

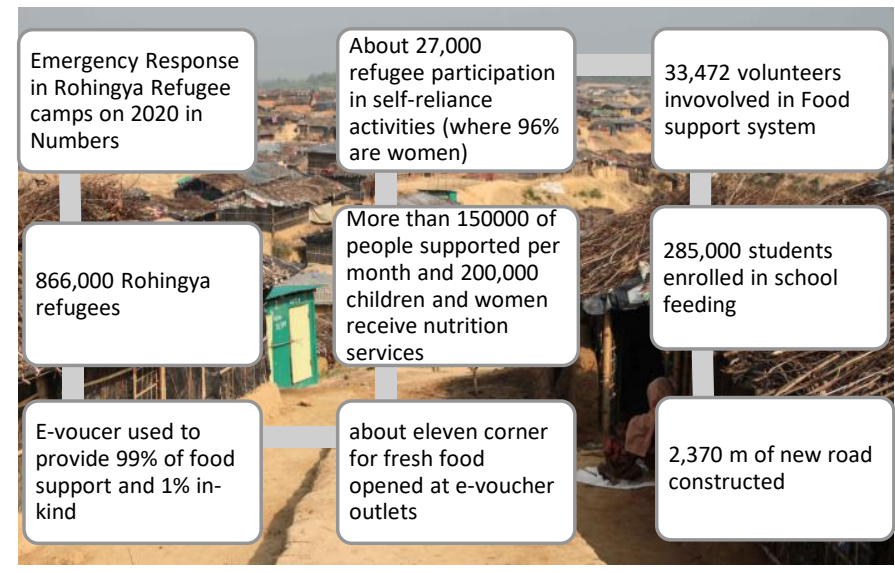

Figure 4. Emergency support for Rohingya in 2020 (Modified by the author from WFP 2021) [38]

\subsection{COVID-19 effects on food security in refugee camps [SDG-2]}

Food is an indispensable part of human life. Food security in the refugee camp is crucial for life and safety as food insecurity has risen globally. People worldwide suffer from food crises, while refuge becomes the most disadvantaged group as they do not have ample access to food from their capacity [39]. The WFP and FAO are the most fundamental organizations, providing food for the Rohingya with thirty other local and international NGOs in refugee camps. They are connected with about 880000 individuals to deliver food [40]. Rohingya refugees rely on others for their livelihoods, where the COVID-19 pandemic adds extra tension both for the donor and refugees. The global effect of pandemics and the continuous downturn of the global economy put pressure on refugee funding and increased food prices [41]. It also influences on emergency humanitarian support system where only food supply gets the highest priority with healthcare service. In turn, it minimizes the availability of other essential services for Rohingya, which is also crucial for their wellbeing. The ISCG [42, 43] figure shows that the continuous budget deficiency hampers crisis management in the largest refugee camps of Rohingya in the world. It also reveals that only the food security system received the most considerable amount of donations for their life and security, as food is fundamental for survival. It also shows that other emergency support services became lean due to extreme budget shortages taken by the food sector.

However, the situation has become steady, but the pandemic intensified the vulnerabilities of the Rohingya. It adjourns the non-essential services influencing economic inability, procuring power, thus frightening existing food security. Ninety-nine percent of food assistance is delivered to Rohingya through e-voucher and one percent in-kind throughout the refugee camps during COVID-19. WFP has initiated new technology named 'blockchain technology' by the digital transfer management system. It provides easy and smooth management of monthly assistance for food by evoucher. In response to the covid crises, WFP organized activities on self-reliance and risk reduction to any disaster. At the same time, it also initiated a school feeding program for children throughout the covid emergency [38].

The social, economic, health, and medical impact of COVID-19 on Rohingya is awful. The effects of COVID-19 detrimentally affected the normal livelihoods of refuge, which complicated food security status in the refugee camps [44]. It also hampers their dietary chart that impacts on their resistance against the infection of the virus [45]. This situation has worsened Rohingya conditions in Bangladesh and Myanmar, and increased numbers of people fled from Rakhine by different routes in the distressed hunt of refugees somewhere else.

The present situation of the COVID-19 crisis and its effects on Rohingya requires short-term policy measures and urgent demand for long-term and transformational assistance, which is holistic and sustainable. Without proper management and preparation to control the virus can aggravate the enduring disasters of Rohingya and challenge sustainability [46].

Moreover, the COVID-19 is an additional threat to the sustainable food system as it added a load with climate change, conflict, and seasonal locust crises in several parts of the world.

\subsection{Effects on funding for Rohingya refugee humanitarian support [SDG-1 and 16]}

This century has witnessed massive migration flows globally. The refugee and displaced people have also increased in numbers around the world. It became a persistent challenge for countries to manage the crises and deal with refugees when they have diverse complexity. Refugee movement and migration are also becoming challenging these days. It is not easy to take them to European and North American countries when the COVID-19 effects linger the whole process of traditional migration and migration of refugees and asylum seekers. However, these are the leading contributory countries to manage the refugee crises around the world.

The COVID-19 is one of the primary causes of the rapid 
increase in global poverty, while more than seventy-one million people pushed into extreme poverty in 2020. This pandemic also triggers the refugee problem again due to the insufficient resources capacity, susceptible health conditions, and the security of the nations. The USA and EU are the most prominent donors for refugee funding, while the effect of Covid-19 exaggerates distastefully. It generates pressure on the refugee funding and crisis management landscape for their financial and domestic policy variations [47]. There is a significant budget deficit in refugee funding, which has augmented since 2018 and drastically fallen in 2021 due to the effects of the COVID-19 on the global economy. According to the recent report, refugee funding decreases every year, and the COVID-19 outburst made everything more complicated when it impacted the shortage of money in the global economy.

Moreover, COVID-19 yields multiple effects on refugee lives, where the funding crises exacerbate multidimensional side-effects that worsen every humanitarian assistance program available for refugees. Financial support is the lifeblood for an economy to survive, while funding refugees for humanitarian support is more than that. The absence of financial support can make everything stagnant, and refuge becomes more marginalized, and their livelihoods can jeopardize. The COVID-19 creates further pressure and threat to global peace and security, and the world witnessed the highest displaced people ever in history. Besides, one hundred people are killed daily due to worldwide arms conflict despite international protection, which challenges global sustainable development.

\subsection{Effects on the education of refugee children and adolescents [SDG-4]}

Education and skill development are an inseparable part of practical livelihoods, including robust resettlement and reintegration. It is the responsibility of the host country to provide educational opportunities to the children when they receive them as a refugee [48]. However, the Bangladesh government has officially opposed formal education to Rohingya as they are transitory and will send them back to Myanmar. Education is a prime key to sponsor active citizenship. In contrast, citizenship can help familiarize them with the broader society as they can take the responsibility of their community in the coming days $[49,50]$. Education can be a lifeline for refugee children for their future life. It can help to uplift their understanding level and equip them in existing political diversity that can contribute to their future sustainability with reintegration and repatriation or resettlement [51]. It can also help to come out from the trauma and abnormalities they experienced during the past. To keep in mind, the government of Bangladesh, with the cooperation of UNICEF and other humanitarian agencies and NGOs, start informal education for refugee children in more than three thirty-two hundred centers (Figure 5). However, this education is not enough for them and not accessible to all, while many were out of school due to limited numbers of informal learning centers in refugee camps. The COVID-19 put pressure on the lean education system for Rohingya refugees and severely impacted their academic life. More than five hundred million students are out of school due to COVID-19. The effect of the COVID-19 amplifies the inequalities in education. The Government of Bangladesh $(\mathrm{GoB})$ postponed all educational services to control the COVID-19 infection and further spread of the virus in response to the epidemic control measures. As a result, all educational institutions from primary to university have been closed since March 2019 in Bangladesh, which was also applied in Rohingya refugee camps and closed all temporary learning centers.

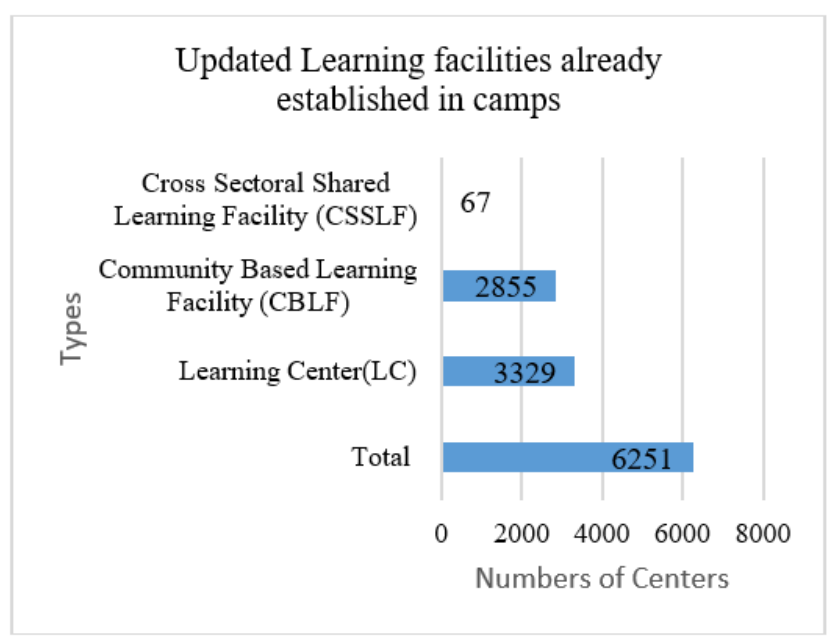

Figure 5. Types and numbers of learning centres [42]

The transitory shutdown of informal learning centers in refugee camps resulted in several challenges while it produced and augmented the earlier social crisis. The pandemic has seized the rights and deprived the children and youth of their right to education. It lifted violence against children with other harmful coping strategies like child labor, child and human trafficking, and early marriage [52]. The NGOs play a crucial role in educating refugee children in their informal learning centers. However, a limited number of skilled teaching staff with inadequate facilities yield sufferings both for the refugee and service providing agencies which became frustrating during COVID-19. Currently, the education service is not providing for them in response to epidemic control. A decent education is far from them as formal education is not yet ensured [51]. Though the international humanitarian agencies continuously urge Bangladesh to start formal schooling [53]. The refugee people are always enthusiastic about their studies. They want to initiate an education based on the Myanmar curriculum as they are willing to return when the situation becomes normal [54]. In response to the instruction, scholars suggested distance learning during the COVID-19 [55]. Besides, new types and numbers of learning centers have increased in refugee camps- i.e., 190354 learning materials distributed to the children and youths, 172 foundations training, and 268 distance education orientations conducted with multimedia classrooms and conference centers for both the children and teachers. Besides pre-school, a library for saving morality and reduce social degradation, education for the disabled, religious centers, recruiting skilled and trained teachers added great positivity among Rohingya. But without formal and interactive classroom education, the aims and goals of educating refugee children will remain unreachable due to covid restrictions.

The recent educational support for refugee children

- Dissemination of learning resources-

The refugee children received about 190,354 books over 30 refugee camps. Students from grades one and two have given eight books, while ten books have given to grades three and four. These books were handed to respond COVID-19 crisis and educational support to refugee children in Rohingya refugee camps, where the academic service has shut down 
since March 2019. However, these children need additional help through direct classroom learning and broader society involvement [42].

- Master Training program for the Foundation ToTThe trained and skilled teaching staff is compulsory for educating refugee children as they are passing critical time. Almost ten batches comprising nearly 172 participants were attended in ToT as a master trainer, while 166 have participated in E-Monitoring Platform Orientation Training. It aimed to build capacity in the persons who are engaged in educating refugee children. There is immense importance for continuous training for these groups in the future [42].

- Training program on Orientation to E-Monitoring Platform-

During the COVID-19 crisis, in-person monitoring becomes challenging both for the service providers and agencies. However, professional development is a continuous process that requires constant training and monitoring with justified incentives and motivation for both the students and teachers. As a result, different stakeholders have participated in the quality benchmark for refugee children's education [42].

- Distance education program orientation-

Training provided to teachers, trainers, and remote supervisors for distance education as COVID-19 crisis forced to avoid physical presence in classroom or center. Training provided on Interactive Radio Instructions and Learning Management System (LMS) by implementing (9) partners to offer education in a crisis period like COVID-19 [42].

The government and international humanitarian agencies are trying to tackle the covid effect in the refugee camps. However, it is not good enough for more than four hundred thousand refugee children due to insufficient logisticseducational arrangement, skilled and trained teachers, and formal education with a certificate through public examinations. Professional and well-educated teaching staff with a well-structured curriculum is also essential for smooth and lifelong learning for their future sustainability. It is also vital to ensure the hand washing and toilet facilities for children in their learning centers to prevent the COVID-19 virus and ensure sustainable development.

\subsection{Socio-economic impact of COVID-19 and well-being of Rohingya Refugee [SDG-8 and 10]}

Every crisis has multidimensional effects on humans and society, while the impact of the COVID-19 affects the most significant part of society and economy [56]. The Government of Bangladesh (GoB) collaborated with different local and global agencies to extend the support system through justifiable access to featured services to build community among the Rohingya refugee population. It has also implemented various policy measures to uphold the peaceful coincide, fortify administrative infrastructure, sustainable and inclusive livelihoods, and restore the environment and ecosystem. The evil effects of the COVID-19 pandemic swiped everywhere, but the suffering increased among vulnerable people like Rohingya. It can also increase the depressing illness among the refugees [57]. It negatively impacts the previous risk management architecture and aggravates the socio-economic impact on adverse coping mechanisms like child trafficking and labor, early marriage, extremist ideology, and movements [51]. Many countries were extended their funds and functions for refugees to respond to the current socio-economic crisis of COVID-19 in refugee camps to range the support service [58].

Rate of JRP Implementation Over Target

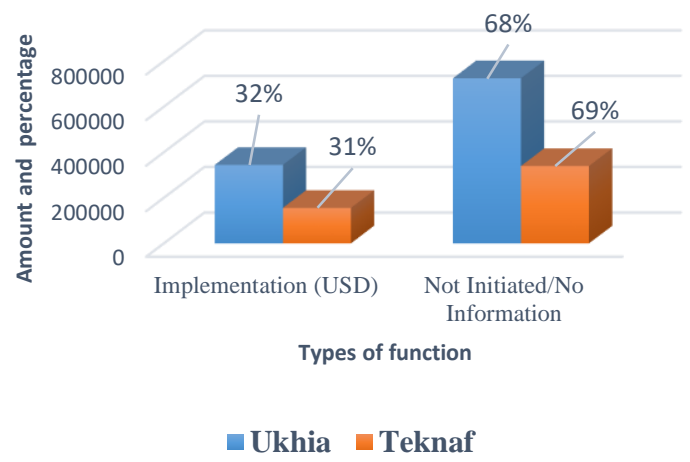

Figure 6. Implementation of joint response plan [52, 59]

The initiation of Protection Emergency Response (PERU) teams in refugee camps extend their functionaries by sending protection messages and responding against the COVID-19 pandemic. They work for the preparation of monsoons and disasters and responds to them. Besides, several focal point centers have arrayed together with PERU teams to protect the child and women and gender-based violence (GBV) from classifying to refer protection cases to increase their security in the refugee camps. The progress and improvement of the Protection Monitoring Framework (PMF) and the virtual child protection training facilitated the direction to case handle and transfer paths. It provided conventional security services across the refugee camps for the most vulnerable community. The children and women need special attention during this COVID-19 crisis as they were more exposed since they fled from Myanmar. These refugee people are hit hardest by the COVID-19 as they are one of the most vulnerable groups. In addition, the repercussion of the current COVID-19 pandemic results in the psychological well-being of vulnerable and mass people. Proper application of rights and opportunities can offer to them to develop their chances to migrate or integrate or repatriate in the future [60]. Their mental health and life are jeopardized seriously because of past incidents, which demand proper address and attention for future policy intervention. Furthermore, the government suspends the development and expansion projects in refugee camps due to the COVID-19 crisis that worsens refugee livelihoods (Figure 6) and confronts the sustainable development goals that need to be addressed appropriately [61]. Besides, the lack of comprehensive migration and refugee management policy in Bangladesh hampers the activities of the local and global aid agencies to promote SDGs in refugee camps.

\subsection{Gender-based vulnerability [SDG-5]}

The COVID-19 pandemic generates diverse and widespread effects on different groups of people. The women and girls are more vulnerable to COVID-19 [62] because of their distinctive physiological and reproductive health practice when it urges for unique water, sanitation, and hygiene (WASH) facilities 
due to their physiology associated with their male counterparts. It is widely evident that this group has experienced augmented challenges during crises and emergencies while Rohingya refugee women and girls, due to COVID 19, are in both situations simultaneously. When they live in a crowded place like camps, these issues are more severe for them as many facilities are not available to them, including clean water and sanitation. They have to collect the drinking water conventionally for their family members that create an extra burden in this pandemic [63]. It also supplements the stress and trauma with mental and physical discomfort in the refugee camps [64]. The COVID-19 pandemic also put pressure on the mental health of different age groups differently, whether they are male or female among the refugee community. Due to their family involvement, they become the front liner in all aspects of the current crises and bearing the extra household burden during covid.

\subsection{Family support during COVID-19 in Rohingya refugee community}

The refugee people have usually confined in a crowded place with pathetic breathing conditions and unemployment that intensify the family crises. The family itself is an institution where children grow up and learn for life long. Rohingya refugees need family involvement to get rid of the traumatic situation and support most children for the future [65]. There are several services provides to refugee people based on their family structure and members. They can help each other in many respect- from the household to the community level.

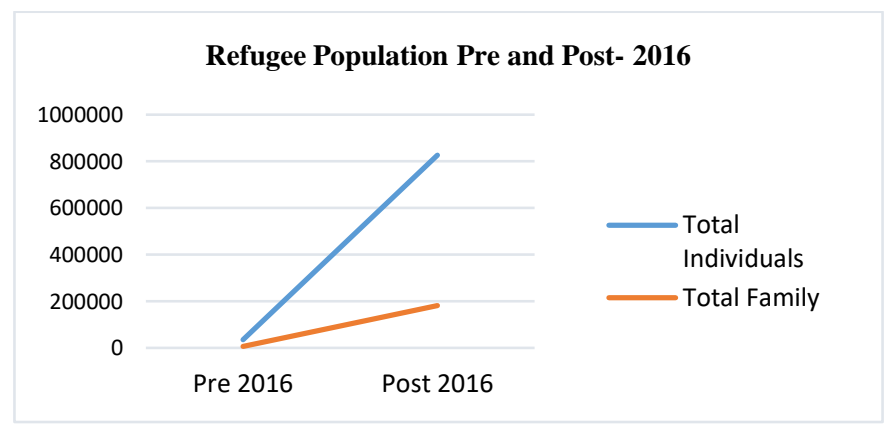

Figure 7. Refugee population- family and individuals [40]

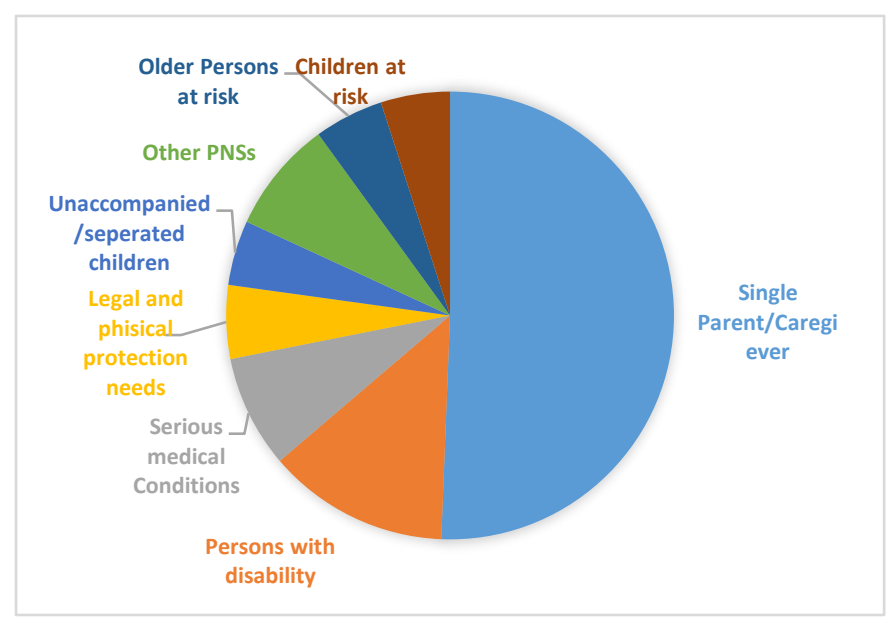

Figure 8. Specific needs of Rohingya individuals [40]
Food, education, health, and many more services become easy when they live together. Rohingya people mostly fled as individuals and persons from broken families (Figure 7), where family is crucial in their distress journey of refugeehood. The significance of family is reemphasized for the Rohingya from a refugee perspective as more than half are children. Refugee children need extra care and support when they move to settle in a peaceful place but have not found it yet. The Rohingya community has its specific vulnerability, where the most alarming one is the single parent and caregiver, which is crucial for both and need to encounter timely (Figure 8 ). As almost all of them are women, the issue became more severe due to typical socio-cultural norms and values in their community and society. These people usually have more children than the average country rate. At the same time, it put pressure on refugees' food and health care facilities, leading to their children's early marriage and ultimately creating further crises [66]. As a result, the government of Bangladesh has implemented the world's most significant biometric registration with international humanitarian agencies for the refugee people and implemented an innovative family unification mechanism for smooth service delivery for the refugee people in their camps. It also helps the aid and other service providing agencies and workers to manage and disseminate the available services on the door to door as an emergency basis during the COVID-19 crisis. A disabled and extreme medical condition person is also in a critical situation due to the COIVD-19. The children and unaccompanied children become helpless as much more support is urgent, besides it becomes worthless due to continued mental shock. Simultaneously, COVID-19 added a social stigma and hurdle for the essential services to mobilize and implement the SDGs for their well-being.

\subsection{Violence against women and children in Rohingya refugee camps [SDG-5]}

Gender-based violence (GBV) is a specific concern for women and girls during a crisis [67] like COVID-19. It reveals that the rate of intimate partner violence has amplified in an epidemic. The current COVID-19 pandemic also results in a thirty percent increase in domestic violence in some countries. The girls and women experience an increased rate of voluntary care, more significant safety risks in and out of households, and psychological well-being [8]. At the same time, they have less access to life-saving support and services [52]. Genderbased violence (GBV) is common in Rohingya refugee camps. A study on (March to April 2019) violence against women and girls, before the Covid outbreak, in Rohingya refugee camps, reported that the rate is going down over the time after their first settlement in refugee camps in Bangladesh [68].

This situation has dramatically changed after the outbreak of the COVID-19 in refugee camps. According to the International Rescue Committee (IRC) report, in a study conducted from July to December 2019, twenty-five percent of the respondents reported that they had experienced genderbased violence in their camps in Cox's Bazar. In addition to that, these women and girls have to fight every day with enormous pre-existing socio-cultural and physiological hurdles in their daily life. Besides, IRC, with other allied partners, conducted a study from January to October 2020. They argue, girls and women "faced an increase in unpaid care work, greater protection risks in and out of their homes, and mental health issues, while simultaneously being less able to 
access life-saving services and support" as reported [52]. This violence remains disgracefully high during the COVID-19 pandemic against girls and women even within their households. The main reasons for this occurrence are as follows-

Excessive household burden along with caregiving liabilities and child aging care;

$>$ Limited access to service, feedback, hotline, and reporting mechanism due to distant and mobile-based communication and fewer female service providers in camps [43];

$>$ In addition, lower participation of women and girls in gender action plans, gender officers training, and gender training for frontline health workers and women leaders and communities.

As a result, the COVID-19 negatively affect gender equity and women empowerment in general in refugee camps. It hit harder than the women in host society as they have preexisting vulnerabilities in their camps. The policy and programs should be more robust to promote sustainable development goals in gender equity in Rohingya refugee camps; however, it depends on many other factors that need to address appropriately.

\section{DISCUSSION AND CONCLUSION}

This paper calls for continuous emergency humanitarian support for sustainable development to the Rohingya refugee community in Bangladesh. They need emergency education and assistance in developing and promoting skills for further development as the refugee crisis becomes global [1]. These people are suffering inadequate support for their livelihoods during the COVID-19 crisis as the covid control measures restricted several services in many ways $[15,69]$. Refugee people live with enduring vulnerability, while the current global pandemic affects the global outcome for lesser aid assistance for survival. Rohingya refugees are having a tough time in Bangladesh after the persecution from Myanmar in 2017. However, significant recent development has improved the sustainability in refugee camps, i.e., construction of cyclone centers, roads, bridges to connect people and homes for the helpless. It also enhances the settings of disaster preparedness in camps when Rohingya live in a disaster-prone area $[29,70,71]$.

In contrast, the COVID-19 outbreak influences refugee life from household to the most complex refugee governance system in a country that is non-signatory to international refugee conventions. The practice matter of humanitarian aid assistance to refugee people has become a growing challenge for international agencies due to the domestic law of the hosting country. It is also ironic at the seventieth anniversary of the global refugee convention, with 9051 legal norms to underpin the rights and opportunities for refuge has become challenged, and many millions of those need transnational protection. The COVID-19 pandemic has become a global crisis, and it swapped worldwide. It led to tension among the Rohingya when the infection increased every day inside the camps. The anxiety and uncertainty of COVID-19 among Rohingya emerge as another most formidable obstacle to overcome. The threat of contracting the virus in refugee camps is high due to limited water, sanitation makes proper washing difficult, and social distancing is next to impossible. Though the local and international aid agencies are taking steps to manage the infections and providing services, governmental restrictions to entry in camps create another hazardous situation to decrease disease risk [72, 73]. It also bounds the critical supplies for access by the refugee. The inadequate supply of clean water and ventilators are the biggest challenge to fight against COVID-19 in refugee camps [74, 75]. It is evident that the leading refugee accepting countries have been slow to accept refugees in recent years when the virus has authorized them to close their borders indefinitely for refugees.

In contrast, many have pushed for resettlement who typically have accepted large numbers of refugees. The refugee survives with a vision of their settlement in their camps while becoming a COVID-19 hotspot. International solidarity is essential for confronting the situation through an inclusive and holistic policy measure for future well-being and sustainability. This cooperation is also critical, particularly for burden-sharing and responsibility in general for all refugees. Besides, displaced people need global protection and assistance for their lives and safety. The current situation of COVID-19 severely affects in humanitarian support system in Rohingya refugee camps. Therefore, global burden-sharing has become central for addressing the COVID-19 pandemic in many countries, including refugees.

The effect of COVID-19 on refuge lives also suggests sustainable policy adaption for future sustainability despite short-term emergency support on food, health, education, and economic inclusion. The central part of them is children and women, who are the most vulnerable but potential for sustainable development of this community. The adequate financial support for promoting sustainable development policy implementations in refugee camps can only help them to get rid of their enduring vulnerability for future well-being. The favorable stands of refugee-hosting and receiving countries are also essential to promote sustainability. The study suggests the universal application for the Global Compact for Migration (GCM) for refugees to ensure sustainable development in the covid era. The governments worldwide are fighting for their populations and economies, while fundamental refugee law and human rights law and practices are crucial for refugee rights protection and global solidarity. However, the positive attitude of the host country during the COVID-19 crisis is fundamental for refugee life and security and to support sustainable development when they live in a country that does not sign any international laws and protocols related to refugees.

\section{REFERENCES}

[1] Yang, A., Liu, W., Wang, R. (2020). Cross-sector alliances in the global refugee crisis: An institutional theory approach. Business Ethics: A European Review, 29(3): 646-660. https://doi.org/10.1111/beer.12288

[2] Sakamoto, M., Begum, S., Ahmed, T. (2020). Vulnerabilities to COVID-19 in Bangladesh and a reconsideration of sustainable development goals. Sustainability, $12(13)$ : 5296. https://doi.org/10.3390/su12135296

[3] Mclean, D. (2020). Calls for inclusion of migrants and displaced in COVID-19 response. https://www.undrr.org/news/calls-inclusion-migrantsand-displaced-covid-19-response, accessed on June 19, 
2021.

[4] Ahsan, S.B. (2018). The Rohingya crisis: Why the world must act decisively. Asian Affairs, 49(4): 571-581. https://doi.org/10.1080/03068374.2018.1528791

[5] O'Brien, M., Hoffstaedter, G. (2020). There we are nothing, here we are nothing! - the enduring effects of the Rohingya genocide. Social Sciences, 9(11): 209. https://doi.org/10.3390/socsci9110209

[6] UNHCR. (2010). Convention and Protocol Relating to the Status of Refugees, The United Nations High Commissioner for Refugees (UNHCR) https://www.unhcr.org/3b66c2aa10.html, accessed on June 5, 2020.

[7] Hossain, A.N.M. (2021). The future of refugee and displaced people: A post COVID-19 perspective. Asian Social $\quad$ Science, $\quad 17(1)$ : $21-33$. https://doi.org/10.5539/ass.v17n1p21

[8] Golesorkhi, L.Z., Fortson, G., Harder, K., Riedmann, T. (2020). Centering community in COVID-19 responses: refugee women's livelihoods in a global pandemic. International Journal of Sociology and Social Policy. https://doi.org/10.1108/IJSSP-07-2020-0332

[9] Aung, S.M.T. (2016). Myanmar ethnic peace process: strategy of the Myanmar government in the ongoing democratic transition. In Myanmar: Reintegrating into the International Community, pp. 349-367. https://doi.org/10.1142/9789814759915_0017

[10] Thorat, S., Newman, K.S. (2007). Caste and economic discrimination: causes, consequences and remedies. Economic and Political Weekly, 4121-4124.

[11] Hossain, A.N.M. (2020a). Unfolding the role of non-state actors in Rohingya refugee crisis at Bangladesh. Košická Bezpečnostná Revue, 10(2): 17-33.

[12] Kipgen, N. (2019). The Rohingya crisis: The centrality of identity and citizenship. Journal of Muslim Minority Affairs, $39(1)$ : 61-74. https://doi.org/10.1080/13602004.2019.1575019

[13] Jo, A., Ca, J. (2019). The Rohingya people: past, present, and future. Lancet, 394(2202): 33139-3. https://doi.org/10.1016/S0140-6736(19)33139-3

[14] Parmar, P.K., Jin, R.O., Walsh, M., Scott, J. (2019). Mortality in Rohingya refugee camps in Bangladesh: historical, social, and political context. Sexual and Reproductive Health Matters, 27(2): 39-49. https://doi.org/10.1080/26410397.2019.1610275

[15] Vonen, H.D., Olsen, M.L., Eriksen, S.S., Jervelund, S.S., Eikemo, T.A. (2021). Refugee camps and COVID-19: Can we prevent a humanitarian crisis? Scandinavian Journal of Public Health, 49(1): 27-28. https://doi.org/10.1177/1403494820934952

[16] El Ghamari, M., Gabriela Bartoszewicz, M. (2020). (Un) Sustainable development of minors in Libyan refugee camps in the context of conflict-induced migration. Sustainability, 12(11): https://doi.org/10.3390/su12114537

[17] Barua, A., Karia, R.H. (2020). Challenges faced by Rohingya refugees in the COVID-19 pandemic. Annals of Global Health, 86(1). https://dx.doi.org/10.5334/aogh.3052

[18] Banik, R., Rahman, M., Hossain, M.M., Sikder, M.T., Gozal, D. (2020). COVID-19 pandemic and Rohingya refugees in Bangladesh: What are the major concerns? Global Public Health, 15(10): 1578-1581. https://doi.org/10.1080/17441692.2020.1812103
[19] Jesson, J., Matheson, L., Lacey, F.M. (2011). Doing your literature review: Traditional and systematic techniques. Evaluation \& Research in Education, 24(3): 219-221. https://doi.org/10.1080/09500790.2011.581509

[20] Milton, A.H., Rahman, M., Hussain, S., et al. (2017). Trapped in statelessness: Rohingya refugees in Bangladesh. International Journal of Environmental Research and Public Health, 14(8): 942. https://doi.org/10.3390/ijerph14080942

[21] Haar, R.J., Wang, K., Venters, H., et al. (2019). Documentation of human rights abuses among Rohingya refugees from Myanmar. Conflict and Health, 13(1): 114. https://doi.org/10.1186/s13031-019-0226-9

[22] Chakraborty, R., Bhabha, J. (2021). Fault lines of refugee exclusion: Statelessness, gender, and COVID-19 in South Asia. Health and Human Rights, 23(1): 237.

[23] UNHCR. (2020). Joint Government of Bangladesh UNHCR Population factsheet as of October 31, 2020. https://data2.unhcr.org/en/documents/details/82872.

[24] Truelove, S., Abrahim, O., Altare, C., Lauer, S.A., Grantz, K.H., Azman, A.S., Spiegel, P. (2020). The potential impact of COVID-19 in refugee camps in Bangladesh and beyond: a modeling study. PLoS Medicine, 17(6): e1003144. https://doi.org/10.1371/journal.pmed.1003144

[25] Chan, E.Y., Chiu, C.P., Chan, G.K. (2018). Medical and health risks associated with communicable diseases of Rohingya refugees in Bangladesh 2017. International Journal of Infectious Diseases, 68: 39-43. https://doi.org/10.1016/j.ijid.2018.01.001

[26] Islam, M.N., Inan, T.T., Islam, A.N. (2020). COVID-19 and the Rohingya refugees in Bangladesh: the challenges and recommendations. Asia Pacific Journal of Public Health, 32(5): 283-284. https://doi.org/10.1177/1010539520932707

[27] Rahman, U. (2010). The Rohingya refugee: A security dilemma for Bangladesh. Journal of Immigrant \& Refugee $\quad$ Studies, $8(2)$ : 233-239. https://doi.org/10.1080/15562941003792135

[28] Zaman, S., Sammonds, P., Ahmed, B., Rahman, T. (2020). Disaster risk reduction in conflict contexts: Lessons learned from the lived experiences of Rohingya refugees in Cox's Bazar, Bangladesh. International Journal of Disaster Risk Reduction, 50: 101694. https://doi.org/10.1016/j.ijdrr.2020.101694

[29] Alam, A., Sammonds, P., Ahmed, B. (2020). Cyclone risk assessment of the Cox's Bazar district and Rohingya refugee camps in southeast Bangladesh. Science of the Total Environment, 135360. https://doi.org/10.1016/j.scitotenv.2019.135360

[30] Ahmed, S., Simmons, W.P., Chowdhury, R., Huq, S. (2021). The sustainability-peace nexus in crisis contexts: how the Rohingya escaped the ethnic violence in Myanmar, but are trapped into environmental challenges in Bangladesh. Sustainability Science, 16(4): 1201-1213. https://doi.org/10.1007/s11625-021-00955-6

[31] Rashid, K.J., Hoque, M.A., Esha, T.A., Rahman, M.A., Paul, A. (2021). Spatiotemporal changes of vegetation and land surface temperature in the refugee camps and its surrounding areas of Bangladesh after the Rohingya influx from Myanmar. Environment, Development and Sustainability, 23(3): 3562-3577. https://doi.org/10.1007/s10668-020-00733-x

[32] Solesbury, W. (2003). Sustainable livelihoods: A case 
study of the evolution of DFID policy. London: Overseas Development Institute.

[33] Homaira, N., Islam, M.S., Haider, N. (2020). COVID-19 in the Rohingya refugee camps of Bangladesh: challenges and mitigation strategies. Global Biosecurity, $1(4)$.

[34] Saifee, J., Franco-Paredes, C., Lowenstein, S.R. (2021). Refugee health during COVID-19 and future pandemics. Current Tropical Medicine Reports, 1-4. https://doi.org/10.1007/s40475-021-00245-2

[35] Alemi, Q., Stempel, C., Siddiq, H., Kim, E. (2020). Refugees and COVID-19: achieving a comprehensive public health response. Bulletin of the World Health Organization, 98(8): 510 https://dx.doi.org/10.2471/BLT.20.271080

[36] Raju, E., Ayeb-Karlsson, S. (2020). COVID-19: How do you self-isolate in a refugee camp? International Journal of Public Health, 65(5): 515-517. https://doi.org/10.1007/s00038-020-01381-8

[37] Khan, M.N., Islam, M.M., Rahman, M.M. (2020). Risks of COVID19 outbreaks in Rohingya refugee camps in Bangladesh. Public Health in Practice, 1: 100018. https://doi.org/10.1016/j.puhip.2020.100018

[38] World Food Program (WFP). (2021). WFP in Cox's Bazar Information Booklet Overview of Programmes, Innovations, Partnerships, Sectors, Cross-Cutting Themes. https://docs.wfp.org/api/documents/WFP0000123163/download/? ga=2.195817580.1513052899 .1616838856-39418886.1616838856.

[39] Elsahoryi, N., Al-Sayyed, H., Odeh, M., McGrattan, A., Hammad, F. (2020). Effect of Covid-19 on food security: A cross-sectional survey. Clinical nutrition ESPEN, 40: 171-178. https://doi.org/10.1016/j.clnesp.2020.09.026

[40] Hossain, A.N.M. (2020). How is ICT shaping the refugee governance landscape in transitional Bangladesh? Central and Eastern European eDem and eGov Days, 338: 203-215. https://doi.org/10.24989/ocg.338.16

[41] Guglielmi, S., Seager, J., Mitu, K., Baird, S., Jones, N. (2020). 'People won't die due to the disease; they will die due to hunger': Exploring the impacts of COVID-19 on Rohingya and Bangladeshi adolescents in Cox's Bazar. London: Gender and Adolescence: Global Evidence.

[42] Inter Sector Coordination Group (ISCG). (2021). Education Sector, Cox's Bazar, Bangladesh. https://reliefweb.int/sites/reliefweb.int/files/resources/da sboard_cxbes_jan_21_ma_v3.pdf, accessed on Feb. 1, 2021.

[43] Vince, G. (2020). The world's largest refugee camp prepares for COVID-19. BMJ, 368 https://doi.org/10.1136/bmj.m1205

[44] Spoerri, M., Ullah, Y., Chloé Nwangwu, N. (2020). The rohingya and COVID-19- towards an inclusive and sustainable policy response, reliefweb. https://reliefweb.int/sites/reliefweb.int/files/resources/T he\%20Rohingya\%20and\%20COVID$19 \% 20-\% 20$ Towards $\% 20$ an $\% 20$ inclusive $\% 20$ and $\% 20$ s ustainable\%20policy\%20response.pdf.

[45] Akter, S., Dhar, T.K., Rahman, A.I.A., Kamal Uddin, M. (2021). Investigating the resilience of refugee camps to COVID-19: A case of Rohingya settlements in Bangladesh. Journal of Migration and Health, 100052. https://doi.org/10.1016/j.jmh.2021.100052

[46] Limon, M.T.I., Jubayer, M.F., Ahmed, M.U., Rahman, H., Kayshar, M.S. (2020). Rohingya refugees and coronavirus Disease-2019: addressing possible jeopardy from the perspective of Bangladesh. Asia Pacific Journal of Public Health, 32(8): 529-530. https://doi.org/10.1177/1010539520947887

[47] Garrett, T.M. (2020). COVID-19, wall building, and the effects on Migrant Protection Protocols by the Trump administration: The spectacle of the worsening human rights disaster on the Mexico-US border. Administrative Theory \& Praxis, 42(2): 240-248. https://doi.org/10.1080/10841806.2020.1750212

[48] Hamilton, R., Moore, D. (2003). Educational interventions for refugee children: Theoretical perspectives and implementing best practice. Routledge.

[49] Cohen, M., Schugurensky, D., Wiek, A. (2015). Citizenship education through participatory budgeting: The case of Bioscience high school in Phoenix, Arizona. Curriculum and Teaching, 30(2): 5-26. https://doi.org/10.7459/ct/30.2.02

[50] Żerkowska-Balas, M., Wenzel, M. (2020). Education through democracy-Civic activation of the youth: Selfreflection on program evaluation methodology. JSSEJournal of Social Science Education, 19(2). https://doi.org/10.4119/jsse-2353

[51] Hossain, A.Z. (2021). Preparedness for education to Rohingya refugee children in Bangladesh: Potentials and challenges to citizenship education. JSSE-Journal of Social Science Education, 20(2). https://doi.org/10.11576/jsse-3980

[52] Joint Response Plan (JRP). (2020). Mid-Term Review Rohingya Humanitarian Crisis, January-July 2020. https://www.humanitarianresponse.info/sites/www.hum anitarianresponse.info/files/documents/files/2020_jrp_ mtr_final.pdf, accessed on Jan. 2021.

[53] Human Rights Watch. (2019). Are We Not Human: Denial of Education for Rohingya Refugee Children in Bangladesh.

https://www.hrw.org/sites/default/files/report_pdf/bangl adesh1219_web_1.pdf.

[54] UNHCR. (2020b). UNHCR-UN appeals for US $\$ 877$ million for Rohingya refugee response in Bangladesh. 2020.

https://www.unhcr.org/news/press/2020/3/5e5cfb984/un -appeals-us877-million-rohingya-refugee-responsebangladesh.html.

[55] Nurul Mostafa Kamal, Z. (2020). Distance education for rohingya children during COVID 19 emergency: bangladesh rohingya response perspectives; challenges, recommendations, and proximities. Distance Education for Rohingya Children during COVID, 19. https://dx.doi.org/10.2139/ssrn.3594676

[56] Bodrud-Doza, M., Shammi, M., Bahlman, L., Islam, A.R.M., Rahman, M. (2020). Psychosocial and socioeconomic crisis in Bangladesh due to COVID-19 pandemic: A perception-based assessment. Frontiers in Public Health, 8: 341. https://doi.org/10.3389/fpubh.2020.00341

[57] Mistry, S.K., Ali, A.M., Irfan, N.M., et al. (2021). Prevalence and correlates of depressive symptoms among Rohingya (forcibly displaced Myanmar nationals or FDMNs) older adults in Bangladesh amid the COVID19 pandemic. Global Mental Health, 8. https://doi.org/10.1017/gmh.2021.24

[58] You, D., Lindt, N., Allen, R., Hansen, C., Beise, J., Blume, S. (2020). Migrant and displaced children in the 
age of COVID-19: How the pandemic is impacting them and what can we do to help. MIGRATION, 10(2).

[59] Inter Sector Coordination Group (ISCG). (2020). Situation report: Rohingya refugee crisis, https://www.humanitarianresponse.info/sites/www.hum anitarianresponse.info/files/documents/files/180325_isc g_sitrep.final_.pdf, accessed on June 20, 2020.

[60] UNESCO. (2020). Guidelines for inclusion: ensuring access to education for all. Paris http://unesdoc.unesco.org/images/0014/001402/140224 e.pdf, accessed on Nov. 15, 2020.

[61] Guglielmi, S., Seager, J., Mitu, K., Baird, S., Jones, N. (2020). Exploring the impacts of COVID-19 on Rohingya adolescents in Cox's Bazar: A mixed-methods study. Journal of Migration and Health, 1: 100031. https://doi.org/10.1016/j.jmh.2020.100031

[62] Mutambara, V.M., Crankshaw, T.L., Freedman, J. (2021). Assessing the impacts of COVID-19 on women refugees in South Africa. Journal of Refugee Studies. https://doi.org/10.1093/jrs/feab044

[63] Rafa, N., Uddin, S.M.N., Staddon, C. (2020). Exploring challenges in safe water availability and accessibility in preventing COVID-19 in refugee settlements. Water International, 45(7-8): 710-715 https://doi.org/10.1080/02508060.2020.1803018

[64] Schmitt, M.L., Wood, O.R., Clatworthy, D., Rashid, S.F. and Sommer, M. (2021). Innovative strategies for providing menstruation-supportive water, sanitation and hygiene (WASH) facilities: Learning from refugee camps in Cox's Bazar, Bangladesh. Conflict and Health, 15(1): 1-12. https://doi.org/10.1186/s13031-021-003469

[65] Scharpf, F., Hecker, T. (2021). A task-shifting and family-focused approach towards mental health care for youth living in refugee camps. https://doi.org/10.21203/rs.3.rs-153988/v1.

[66] Uddin, M.A. (2021). The meaning of marriage to the Rohingya refugees, and their survival in Bangladesh. Journal of Refugee Studies. https://doi.org/10.1093/jrs/feaa054

[67] Freedman, J. (2016). Sexual and gender-based violence against refugee women: A hidden aspect of the refugee" crisis". Reproductive Health Matters, 24(47): 18-26. https://doi.org/10.1016/j.rhm.2016.05.003

[68] Xchange. (2019). The Rohingya Survey 2019. http://xchange.org/reports/TheRohingyaSurvey2019.ht $\mathrm{ml}$.

[69] Kluge, H.H.P., Jakab, Z., Bartovic, J., d'Anna, V., Severoni, S. (2020). Refugee and migrant health in the COVID-19 response. The Lancet, 395(10232): 12371239. https://doi.org/10.1016/S0140-6736(20)30791-1

[70] Zaman, S., Sammonds, P., Ahmed, B., Rahman, T. (2020). Disaster risk reduction in conflict contexts: Lessons learned from the lived experiences of Rohingya refugees in Cox's Bazar, Bangladesh. International Journal of Disaster Risk Reduction, 50: 101694. https://doi.org/10.1016/j.ijdrr.2020.101694

[71] Quader, M.A., Dey, H., Malak, M.A., Sajib, A.M. (2021). Rohingya refugee flooding and changes of the physical and social landscape in Ukhiya, Bangladesh. Environment, Development and Sustainability, 23: 46344658. https://doi.org/10.1007/s10668-020-00792-0

[72] Saifee, J., Franco-Paredes, C., Lowenstein, S.R. (2021). Refugee health during COVID-19 and future pandemics. Current Tropical Medicine Reports, 1-4. https://doi.org/10.1007/s40475-021-00245-2

[73] Kamrujjaman, M., Mahmud, M., Ahmed, S., et al. (2021) SARS-CoV-2 and rohingya refugee camp, Bangladesh: Uncertainty and How the government took over the $\begin{array}{lll}\text { situation. } & \text { Biology, } & 124 \text { (2): }\end{array}$ https://doi.org/10.3390/biology10020124

[74] Cowper-Smith, Y., Muhammad, S. (2021). COVID-19 in Cox's Bazar. The Statelessness and Citizenship Review, 3(1): 148-154.

[75] Chattoraj, D., Ullah, A.A., Hossain, M.A. (2021). The COVID-19 Pandemic and the Travails of Rohingya Refugees in the Largest Bangladeshi Refugee Camp. Volume 1: Community and Society, 165. 